\title{
Distribution and accumulation in post-1980 advanced capitalism
}

\author{
Aldo Barba \\ Università di Napoli Federico II, Italy \\ Massimo Pivetti ${ }^{*}$ \\ Università di Roma La Sapienza, Italy
}

\begin{abstract}
The paper tries to build a framework of the interconnections between income distribution and accumulation for the years after 1980. On the basis of this framework it is argued that it was primarily the weakening of the inducements to invest that improved the attractiveness of financial investments, rather than the other way round. The overall effect on investment of financial sector enlargement was negative, but for the reason that it contributed to bring about a change in income distribution unfavourable to the expansion of demand, while permitting only a temporary disconnection of demand from the distributive change. The reader's attention is then drawn to the element of continuity that can be detected between the current European economic policy of austerity and the process of substitution of loans for wages experienced by a large section of advanced capitalism up to the 2007 crisis. The article concludes on the question of long-run social stability within advanced capitalism.
\end{abstract}

Keywords: income distribution, accumulation, finance, austerity, social stability

JEL codes: D33, E22, E44, E61, E62

\section{INTRODUCTION}

According to the principle of effective demand to which this paper will adhere, output is demand-determined in the short and the long run alike. Both actual and potential output are seen as essentially determined by the expenditure on consumption and the expenditure on investment that the system is capable of generating over time, so that to ask what determines the course of the system's productive potential amounts very much to the same thing as asking what determines the long-term changes in the sums spent on consumption and in those devoted to investment. Income distribution is regarded as the fundamental determinant of final demand, and, through final demand, of the inducement to invest. On the other hand, any weakening or strengthening of the inducement to invest is seen as tending in turn to act, through its impact on the level of employment and wage earners' bargaining power, as a cause of distributive changes. By distinguishing between investments aimed at the widening of the economy's productive structure and investments aimed at its change, in what follows we try to build a framework of the interconnections between distribution and accumulation for the years after 1980.

* We wish to thank an anonymous referee of the journal for comments and suggestions. 
We argue, on the basis of this framework, that the distributive changes experienced by advanced capitalism over the last 3 decades have tended to feed upon themselves.

In our framework of the circuit connecting distribution, final demand and accumulation, finance plays a merely permissive role, unless capable of impacting on income distribution or of disconnecting final demand from distribution. Now, especially in the Anglo-Saxon world, during the last 3 decades finance did actually impact on income distribution, essentially through an astonishing expansion of profits in a rapidly expanding financial services industry. And in that same world, the development of finance also succeeded in disconnecting, albeit temporarily, final demand from distribution through a massive process of substitution of loans for wages.

Finally, austerity and the strictly connected European drive to privatizations are discussed, in the light of the interconnections between income distribution and accumulation previously put forward. We contend that, following the process of substitution of loans for wages experienced by a significant section of advanced capitalism up to the financial and economic crisis of 2007, the current European economic policy of austerity can be read as yet another attempt to bring about - this time in a context of fully-fledged stagnation - a continued expansion of profits and top management income disconnected from that of all other incomes. We see this policy as bound eventually to bring into question the very legitimacy of the social system.

This article is organised as follows. The next two sections discuss the relationship between income distribution and accumulation with respect to the two stages of accumulation that are discernible for advanced capitalism since the end of the Second World War. Section 4 complements the analysis of the distribution-accumulation relationship by focusing on investments aimed at changes in the methods of production and in the industry mix of output - the very changes by which the pace of investment was mainly fuelled during the last 3 decades. Section 5 reviews the distributionaccumulation relationship since around 1980 up until the crisis. The role of finance is discussed in Section 6. It is there contended that the overall effect on investment of the financial sector enlargement over the last 30 years was negative, in that it contributed to bring about a change in income distribution unfavorable to the expansion of demand, while at the same time providing only a temporary disconnection of demand from the distributive change. Section 7 deals with the European economic policy of austerity, in the light of the interconnections between income distribution and accumulation previously put forward. Section 8 concludes on the question of social stability and the overall prospective picture of advanced capitalism.

\section{TRENDS IN FIXED CAPITAL FORMATION}

When looking at the post-war long-term trend in gross fixed capital formation in the major advanced economies, two stages of accumulation are clearly discernible. Despite some differences between countries, over the period before the divide of the late 1970s average annual growth rates of both gross fixed capital formation and gross domestic product doubled those for the period after 1980 (see Table 1). The difference between these two periods is even more marked if only non-residential fixed capital formation is considered, since during a portion of the second 30-year period (the 2000s up to the outbreak of the crisis) residential investment has been the most dynamic component of fixed capital formation, especially in the Anglo-Saxon countries.

Not only the pace but also the composition of non-residential fixed capital formation suffered significant changes since the end of the 1970s/beginning of the 1980s. 
Table 1 Gross fixed capital formation and gross domestic product: average annual growth rates at constant market prices

\begin{tabular}{lccc}
\hline Gross fixed capital formation & $1951-1980$ & $1981-2010$ & $(1981-2007)$ \\
\hline Canada & 4.9 & 3.3 & $(3.7)$ \\
Germany & 5.4 & 1.3 & $(1.6)$ \\
France & 5.4 & 1.8 & $(2.4)$ \\
Italy & 5.7 & 1.3 & $(1.9)$ \\
United Kingdom & 5.7 & 3.0 & $(3.9)$ \\
United States & 3.6 & 2.9 & $(4.0)$ \\
Japan $^{\mathrm{a}}$ & 11.3 & 1.1 & $(1981-2007)$ \\
\hline Gross domestic product & $1951-1980$ & $1981-2010$ & $(2.8)$ \\
Canada & 4.4 & 2.6 & $(2.0)$ \\
Germany & 5.2 & 1.8 & $(2.1)$ \\
France & 4.6 & 1.8 & $(1.8)$ \\
Italy & 5.1 & 1.5 & $(3.1)$ \\
United Kingdom & 2.6 & 2.4 & $(2.6)$ \\
United States & 3.6 & 2.8 & \\
Japan & & &
\end{tabular}

Note: ${ }^{\mathrm{a}}$ From 1953.

Source: OECD, AMECO.

The most significant of these changes was undoubtedly the rapidly increasing weight of investment in information and communication technologies (ICT). Figure 1 shows, for the USA, the behaviour of the three main categories of private non-residential gross fixed capital formation as a percentage of GDP. As can be seen, they follow a very different path since the beginning of the 1980s: structures (buildings other than dwellings and other structures) as a share of GDP shrank throughout the period, only to recoup during the boom in overall construction spending that characterized the 2000s; investments in machinery and equipment also fell after 1980, although they recorded some growth during the 'roaring' 1990s. Only investments in information processing equipment and software kept growing as a share of GDP after 1980, reaching a peak of 4.8 per cent of GDP in 2000, thus partially offsetting the slowdown of the other investment categories and driving the investment boom of the 1990s. At the turn of the century, all categories of non-structure investment lapsed, leaving structures as the only significant source of accumulation in the US. ${ }^{1}$

The growing share of ITC investment in total non-residential gross fixed capital formation has not been limited to the US. As can be seen from Table 2, between 1980 and 2000 this share doubled in Canada, in Japan and in the US; it almost tripled in Australia, Netherland and France, and quadrupled in the UK.

Important changes also took place in the growth rates of fixed capital formation in manufacturing and in non-manufacturing. Figure 2 shows for the US the behaviour of private

1. As pointed out in the 2010 Economic Report of the President, not only 'IT investment grew at the historically tepid pace of 6 percent per year from 2003 to 2007, far below pre2000 growth rates', but '[i]n the recovery following the 2001-2002 recession, [also] the peak value of non-IT equipment as a share of GDP was only $4.3 \%$ (in 2006), a level that does not even match the historical average value of that series in the period from 1980 to 2000' (Council of Economic Advisers 2010, p. 127). 


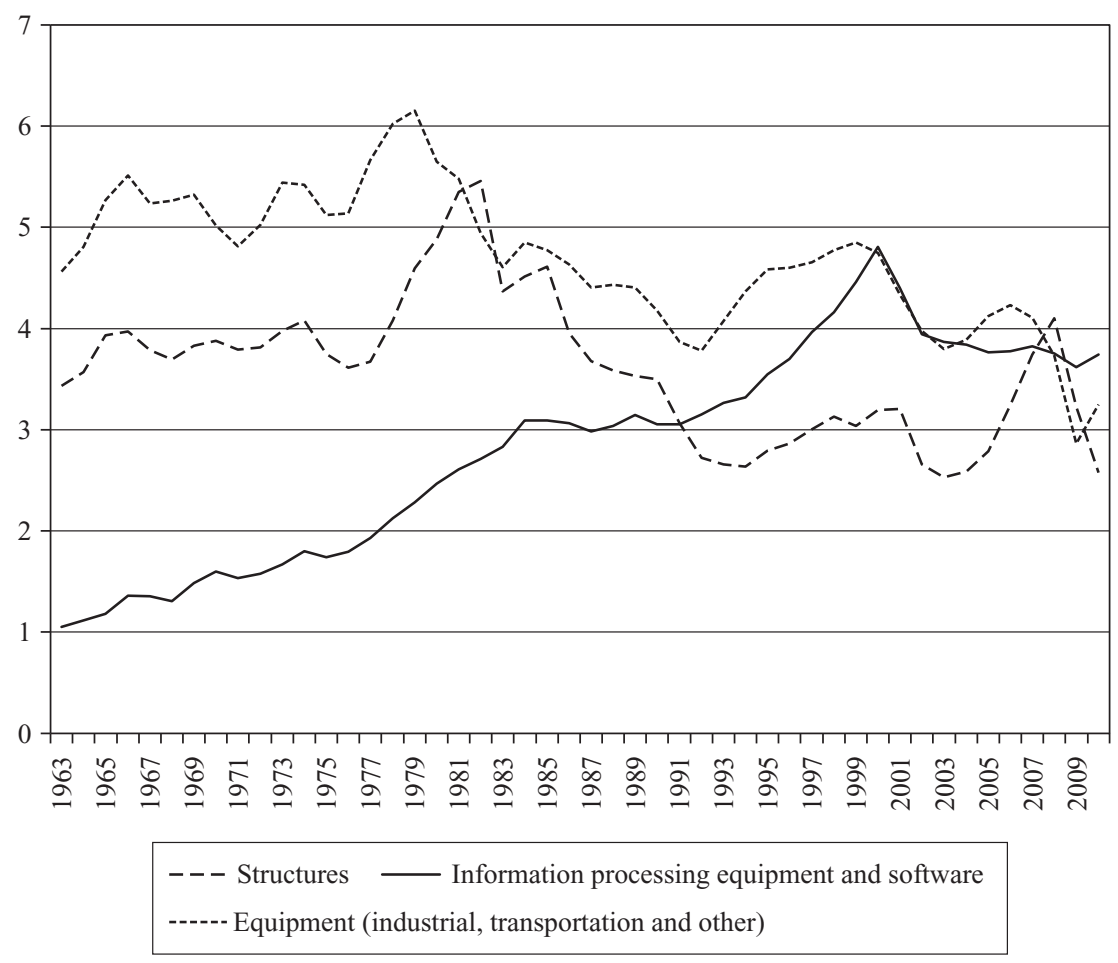

Source: BEA.

Figure 1 US private nonresidential fixed investment by type, in percentage of GDP

Table 2 ICT investment in non-residential gross fixed capital formation, in percentage of total non-residential gross fixed capital formation

\begin{tabular}{lrrrrrrrr}
\hline & 1980 & 1985 & 1990 & 1995 & 2000 & 2005 & 2006 & 2007 \\
\hline Australia & 7.4 & 9.7 & 15.3 & 19.1 & 24.8 & 14.9 & 14.3 & 13.3 \\
Canada & 9.1 & 11.1 & 13.2 & 16.8 & 20.6 & 17.6 & 17.0 & 16.5 \\
France & 7.6 & 12.2 & 11.9 & 13.9 & 19.2 & 17.4 & 17.0 & 16.1 \\
Germany & 11.6 & 13.2 & 13.9 & 13.3 & 17.5 & 14.4 & 14.0 & 14.1 \\
Italy & 8.5 & 10.7 & 12.1 & 13.0 & 14.6 & 11.6 & 10.9 & 10.6 \\
Japan & 7.5 & 8.6 & 8.9 & 10.8 & 15.0 & 14.3 & 13.4 & 13.2 \\
Netherlands & 7.6 & 12.1 & 14.7 & 15.7 & 19.9 & 22.0 & 22.3 & 19.5 \\
Spain & 8.6 & 14.0 & 13.7 & 12.5 & 14.7 & 12.7 & 13.0 & 13.6 \\
United Kingdom & 7.9 & 13.9 & 15.9 & 23.0 & 30.0 & 24.6 & 24.7 & 23.8 \\
United States & 16.0 & 21.5 & 23.8 & 27.2 & 32.0 & 26.5 & 25.6 & 26.0 \\
\hline
\end{tabular}

Source: OECD.

investment in these two industry groups as a share of GDP. While manufacturing investment fell to 1.5 per cent in 2007 from its peak value of 2.8 per cent in 1981, non-farm non-manufacturing investment showed much more resilience, accounting in 2007 for about the same share of GDP as in the early 1980s. This resilience was mainly due 
130 Review of Keynesian Economics, Inaugural Issue

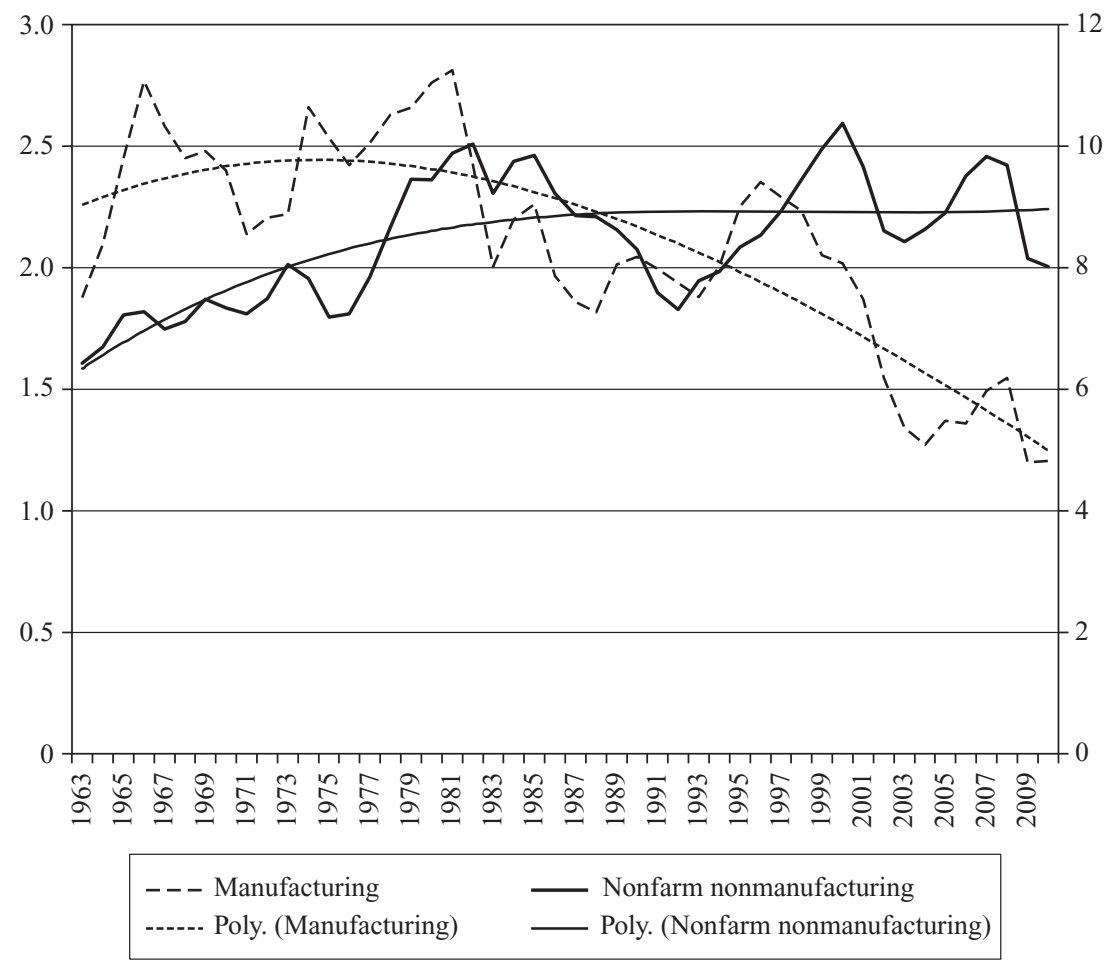

Source: BEA.

Figure 2 US private nonresidential fixed investment by industry in percentage of GDP (manufacturing left scale; nonfarm nonmanufacturing right scale)

to the expansion of investment in financial intermediation, education, health and social work, community social and personal services, and real estate.

The gap between investment growth in the service industries and investment growth in manufacturing is even more marked if one takes into consideration only ICT investment in the two industry groups. Here the point is that over the period under consideration a strict connection between ICT investment and investment in the service sector established itself a connection which worked both ways: from the enlargement of the service sector to the growth of ICT investment, because ICT is dominant in the service sector; from the development of ICT to the enlargement of the service sector share in total value added, because ICT has allowed the outsourcing of many services previously produced within the manufacturing sector itself. This connection between ICT and the service sector can be detected also for the rest of advanced capitalism, where since the late 1970s the increase of the service share in total value added has been as marked as in the USA.

The overall picture emerging from this analysis reveals that in the years since 1980 capital formation within advanced capitalism consisted mainly of ICT investments, partly offsetting a decline in investments in structures and non-ICT equipment. This trend reached its maximum intensity in the 1990s, when a surge in information processing equipment and software investment, mainly concentrated in non-manufacturing industries, drove an investment boom in equipment investment as a whole. It is worthy 


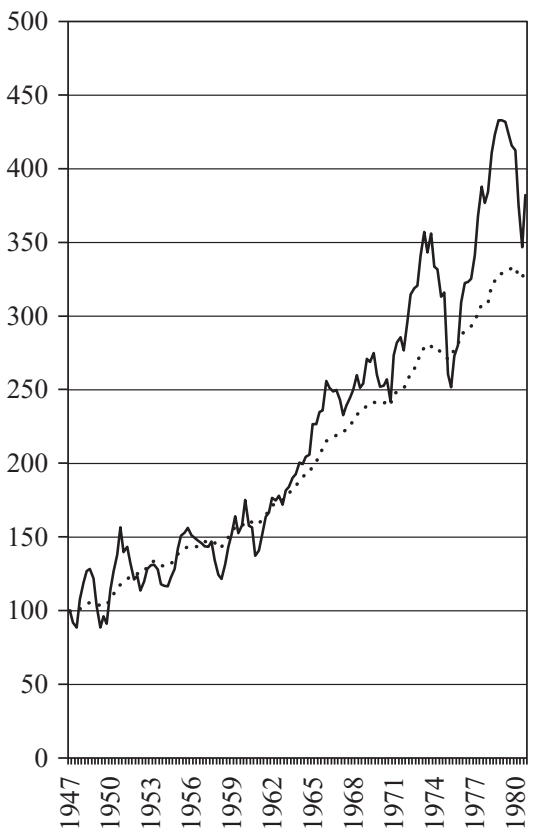

Real gross private investment $(1947=100)$ ..... Real gross domestic product $(1947=100)$

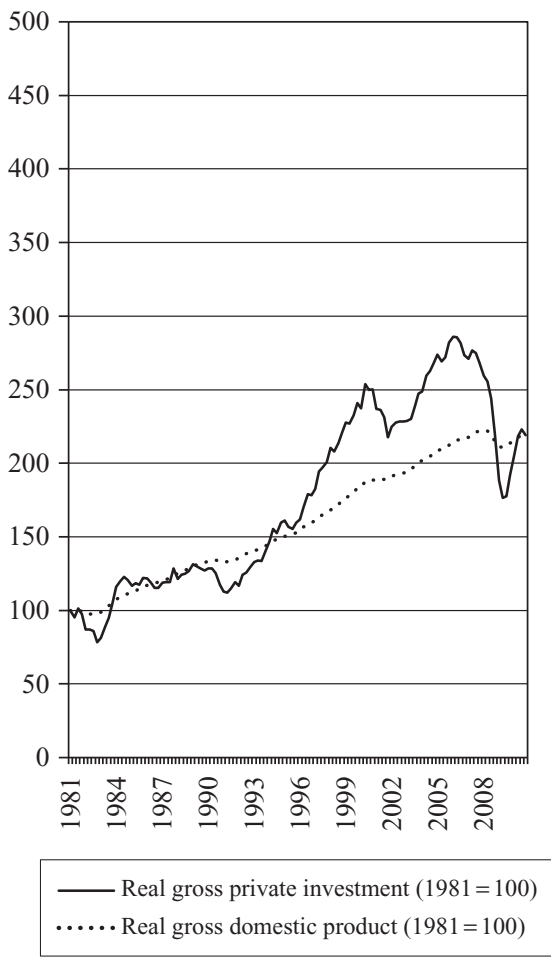

Source: BEA.

\section{Figure 3 Two accumulation cycles in the US}

of note that this investment surge occurred in a context of relatively contained output growth. Indeed, while until the beginning of the 1990s the growth of fixed capital occurred parallel with that of output, during the 1990s this connection was lost (see Figure 3), so that the 'buoyancy' of those years in business fixed investment can hardly be thought of as a function of changes in output. As has been observed,

after moving more or less in line with real output throughout the 1980s and the early 1990s, real business investment pulled away in the following years in some countries. While investment is generally more volatile than output, such a large and persistent gap between the two series is difficult to explain by traditional 'accelerator' effects alone. This raises the issue of sustainability of investment, unless the recent buoyancy can be accounted for by other determinants that have themselves evolved in a sustainable way. (OECD 2001, p. 137) ${ }^{2}$

We shall return to these 'other determinants' in section 4 below. For the moment, we can conclude that the pace of investment during the last 3 decades was mainly fuelled by changes in the productive structure - technological changes and changes in the

2. The disconnection during the 1990s between output growth and investment growth is even more striking if one considers that ICT investment as a share of GDP grew still more markedly when measured in volume, given the falling prices of computers and software recorded since the beginning of the 1980s. 
industry-mix of output - and that it was more sustained in the USA, especially during the 1990s, where both these phenomena occurred more intensively.

\section{ON THE RELATIONSHIP BETWEEN INCOME DISTRIBUTION AND INVESTMENT}

As was pointed out in our introduction, we view income distribution as the chief determinant of final demand, and, through final demand, of investment. We acknowledge, however, that since income distribution is ultimately determined by the level of employment, and the latter depends on aggregate demand, any weakening or strengthening of the inducement to invest may act in turn as a cause of distributive changes.

With a view to forming a convincing picture of the order in which these two causal relationships followed one another during the years after 1980, one may take the policy change which took place within advanced capitalism at the end of the 1970s as the starting point, or primum movens, of the whole process. Though that policy change itself cannot strictly be regarded as a primum, having in turn been brought about by the distributive changes eventually determined by a previous long period of high employment, it remains however true that the shift away from full employment to fighting inflation, for the very fact of having been a policy change, was not a necessary event - it could have taken place differently, or not taken place at all (there is no doubt, for example, that in continental Europe it took place quite differently than in the UK and the USA; on this, see Pivetti 2011). It is in this sense that the policy change in question may be regarded as a primum movens.

From this perspective, then, the distributive change experienced by advanced capitalism first appears as the effect of the abandonment of full employment as the primary policy objective; but later on, once firmly established, the change in distribution acted instead as a cause of weaker inducements to invest, through its negative impact on the propensity to consume. Indeed, as Keynes put it, 'capital is not a self-subsistent entity existing apart from consumption. On the contrary, every weakening of the propensity to consume regarded as a permanent habit must weaken the demand for capital as well as the demand for consumption' (Keynes 1936 [1964], p. 106). ${ }^{3}$ There is no doubt that an interconnection between changes in distribution and accumulation can be detected, albeit in an inverted order, in both the first and second 30-year periods after World War II. Now, in the analysis of this interconnection, it is useful to distinguish between investments aimed at the widening of the economy's productive structure and investments aimed at its change (in the methods of production and in the composition of output). Although there is a relationship between the widening of productive capacity and its change (since growth is never just a scale phenomenon but occurs continuously through changes in the productive structure), it is nonetheless true that the two types of investment are different in nature, in that they are essentially acted upon by different causes.

As to the former of the two types of investment just referred to, changes in distribution act upon the expansion or the contraction of productive capacity through their

3. Propositions such as this are frequent both in the General Theory and in Keynes's previous and successive writings. The fact however remains that Keynes's analysis of the inducement to invest centres round his 'marginal efficiency of capital' schedule, which, as we know, through the neoclassical synthesis etc., has eventually led to the actual re-proposition of the orthodox causal relationship between saving and investment, at least with respect to long-period analysis. 
impact on final demand; the additional point one should also acknowledge is that expansions or contractions of the system's capacity affect in turn distribution and final demand through their impact on employment and wage earners' bargaining power, thus setting in motion either a virtuous or a vicious circle. Quite different is the case as concerns the latter type of investment referred to above. Here the relationship between distribution and accumulation is significantly more complex.

\section{NON-CAPACITY VERSUS CAPACITY-GENERATING INVESTMENT}

Changes in the productive structure may be conceived as renewals and/or failed renewals of already existing capital equipment, in the face of: (a) the availability of new methods of production; (b) changes in the industry mix of output - notably, changes in favour of the service industries; and (c) the non-replacement of existing equipment due to its installation abroad having become more profitable.

With respect to new methods of production, it is especially when there occur shifts in strength relations capable of affecting normal distribution in wage earners' favour that the effort to sustain the profitability of investment induces anticipated replacements of existing capital, essentially with a view to introducing labour-saving techniques. These anticipated investments, by themselves, act positively upon aggregate demand. But the ensuing formation of technological unemployment is bound to check the rise of wages, thereby contributing to sustain profitability at the expense of final demand. Moreover, changes in the composition of the economy's fixed capital in favour of less durable goods (think of computers and other ICT equipment) reduce the average life of producers' equipment, thereby bringing about increasingly accelerated replacements of parts of the existing capital stock. ${ }^{4}$ This, again, by itself, tends to exert a positive impact on aggregate demand and employment, hence on wage earners' bargaining power (it is as if fixed capital became increasingly similar to circulating capital, which must be entirely reproduced year by year). But as the average life of producers' equipment becomes shorter, the normal allowances for average indirect costs per unit of output rise, and, all the rest remaining the same, gross profit margins rise with them. The resulting higher ratio of prices to money wages obviously has a negative impact on aggregate demand. ${ }^{5}$ Now, the overall impact on activity levels of the anticipated replacement of existing equipment and of the increasingly accelerated replacement of parts of the existing stock of fixed capital cannot be determined a priori, as it depends on the relative intensity of their direct positive effects on aggregate demand and of the negative ones they instead exert, indirectly, through income distribution.

Partially analogous is the case regarding changes in the productive structure resulting from the shift away from manufacturing to the service sector. To the extent to which these changes in the industry mix of output take the form of an anticipated replacement of equipment in the former sector with new equipment in the latter, there will also in this case be a positive impact on aggregate demand and employment, hence on wage earners' bargaining power. Sooner or later, however, since the capitallabour ratio in manufacturing is higher than in most service industries, ${ }^{6}$ the negative

4. Cf. Council of Economic Advisers 1995, p. 53.

5. On the determinants of normal gross profit margins and the share of wages in value added, see Pivetti 2009, App. 2, pp. 227-228.

6. While the share of gross fixed capital formation in the value added of the service sector is currently higher than in the value added of the manufacturing sector, the capital-labour ratio is 
134 Review of Keynesian Economics, Inaugural Issue

Table 3 Manufacturing imports from China, in percentage of total domestic value added in manufacturing

\begin{tabular}{lcccrrr}
\hline & 1995 & 1999 & 2000 & 2005 & 2007 & 2008 \\
\hline Canada $_{\text {France }}^{\mathrm{a}}$ & 3.3 & 5.0 & 5.8 & 15.3 & 19.9 & 23.6 \\
Germany & 1.9 & 3.9 & 5.0 & 10.1 & 13.3 & 14.8 \\
Italy & 2.1 & 3.3 & 4.2 & 8.7 & 10.4 & 11.6 \\
Japan & 1.6 & 2.2 & 3.0 & 5.8 & 8.2 & 9.1 \\
United Kingdom $_{\text {United States }}^{\mathrm{a}}$ & 2.6 & 4.1 & 4.9 & 10.5 & 13.2 & 13.7 \\
& 2.7 & 4.3 & 5.8 & 11.5 & 14.8 & 17.9 \\
& 3.1 & 5.9 & 7.2 & 15.4 & 18.7 & 20.5 \\
\hline
\end{tabular}

Note: ${ }^{\mathrm{a}}$ Data for France and US in 1995 are in percentage of total industry (manufacturing plus energy).

Source: OECD.

effect on investment caused by the non-replacement of equipment in manufacturing and by this sector's relative contraction is likely to outweigh the positive one caused by the larger capital formation in the service sector. It should also be taken into account that the change in the industry mix of output in favour of services tends to depress the average level of wages in the economy through the connected change in the composition of employment: the average level of workforce specialization required by firms is lower in the service industries; moreover, these industries are characterized by a markedly minor incidence of collective bargaining arrangements and employment protection legislation (see Mishel et al. 2009, pp. 183-186; Salverda and Mayhew 2009).

Finally, as regards case (c) above, especially worthy of attention is the fact that major determinants of the failed renewals of existing capital equipment in the manufacturing sector, as well as of its relative contraction within advanced capitalism, have been the so-called relocations - the stream of investments in plant and equipment to low-wage developing countries, ${ }^{7}$ prompted, in the new context of full capital liberalization, by their higher profitability - and the increasing flows of imports of manufacturing from those same countries (see Table 3). Both the stream of direct investments abroad and that of manufacturing imports have helped to change distribution within

instead lower in most service industries as compared to that for the total economy. In particular, trade, social and personal services, hotels and restaurants show capital-labour ratios about half the ratio for the total economy; transport and communications services, on the other hand, have a very high capital-labour ratio relative to the overall economy (on this, see OECD 2005, p. 46). 7. The importance of foreign direct investment (FDI) as a determinant of global capital formation should not be overrated, since the enormous flows of FDI recorded up until the turn of the century was not paralleled by the growth of global fixed capital formation (which actually registered a negative growth during the 1996-1999 period). However, independently of the huge number of corporate takeovers which took place between developed nations without bringing about any growth of their capital stock, it remains true that low-wage developing countries have recorded significant inflows of greenfield investments from high-wage developed countries. As stressed by the OECD, 'In recent years, an increasingly large share of FDI flows has been through mergers and acquisitions (M\&As). This partly reflects a flurry of transatlantic corporate takeovers, and partly the large-scale privatisation programmes that were implemented throughout much of the world in the 1990s. In developing countries, however, greenfield investment has remained the predominant mode of entry for direct investors, followed by foreign companies' participation in privatisations' (OECD 2002, pp. 7-9; see also UNCTAD 2010, pp. 4-9). 
advanced capitalism through their impact on the volume and composition of employment, as well as through the leverage they exerted on wage bargaining by the mere threat of relocations of productive facilities and direct foreign competition. Here again, once attained, the distributive change reacts in turn on the inducement to invest through its negative impact on the expansion of final demand. It should be noted that, differently from the previous cases (a) and (b), here the negative impact exerted by the distributive change on aggregate demand is not compensated for, even temporarily, by higher activity levels generated by anticipated and accelerated replacements of existing equipment: with the relocations, there merely occurs a process of substitution of investments abroad for domestic investments.

\section{SOME SUMMING UP ON THE DISTRIBUTION-ACCUMULATION RELATIONSHIP}

The above set of interconnections can be synthesized by the circuit diagram shown in Figure 4. This shows, first of all, the circuit connecting distribution, final demand and accumulation (the external thick arrow). It then shows the causal relationship from distribution to accumulation - that is, the direct impact of changes in normal distribution on the inducement to invest (the south-east thick internal arrow) - and the causal relationship from accumulation to final demand (the north-east thick internal arrow). The internal part of the figure covers the other three factors capable of acting upon accumulation and income distribution: technical changes, changes in the industry mix of output and net direct investment abroad. Technical changes impact on accumulation and interact with income distribution, while sectoral changes and net direct investments abroad impact on both income distribution and accumulation.

In the light of our overall picture of the interconnections between distribution and accumulation, one can say, with reference to the actual experience of advanced

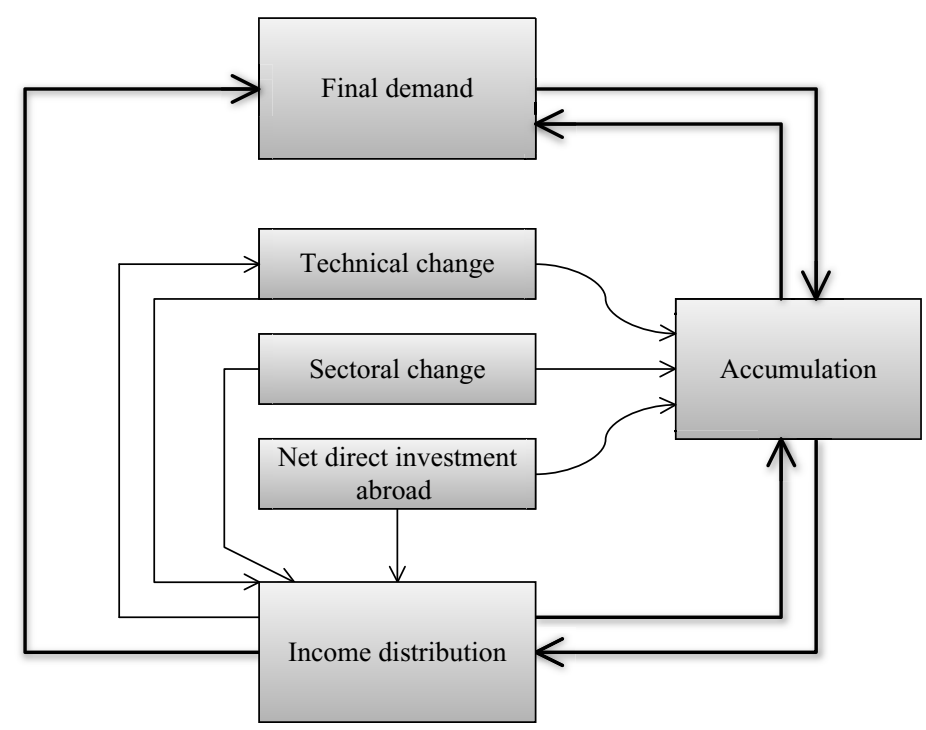

Figure 4 Distribution, final demand and accumulation 
capitalism since around 1980 up to the crisis, that a likely positive influence on investment initially exerted by an epoch-making policy shift - an improved 'state of confidence' among investors due to the change in the parties' relative strength, with higher normal rates of return being expected on any investment project - was eventually more than compensated for by the reduced leverage of final demand. As to the interconnections between distribution and changes in the productive structure, four points of our analysis appear to us as especially relevant. First, because of the changes in normal distribution in favour of profits throughout the period under consideration, the inducements to invest with a view to sustaining profits by changing the methods of production in use must have been weaker than they would otherwise have been. ${ }^{8}$ Second, the net impact on investment of the linkages one can detect for the period under consideration between technological change and the change in the industry mix of output is most uncertain; in fact, if on the one hand the continuous shift over the last 30 years from goods-producing to service industries, resulting from trade and deindustrialization, has had a positive impact on the volume of investment through streams of anticipated and accelerated replacements of existing equipment, on the other that shift has contributed to check the rise of wages, thereby weakening the incentives to invest through the circuit connecting distribution, final demand and accumulation. Third, a negative impact on wages and on aggregate demand has been exerted by the stream of direct investments abroad: in this case the contraction of domestic productive capacity in the goods-producing sector was simply substituted for by the formation of additional capacity abroad, so that the net impact on domestic investment was definitely negative. Finally, with the progressive breakdown of wage earners' bargaining power produced by this framework of interconnections, the distributive change has tended to feed upon itself.

It is to this final point which we have to look for the basic tendency of the period under consideration. With respect to this tendency, any positive influence on the volume of investment the technological and sectoral changes may have exerted presents itself as a factor of a more secondary and temporary nature.

\section{THE ROLE OF FINANCE}

The previous analysis has given no role to financial factors. From our perspective, in fact, finance plays a merely permissive role, unless it is capable of impacting on income distribution, or of 'disconnecting' final demand from distribution. The latter case is well represented by the process of substitution of loans for wages, which, through the easing of households' liquidity constraints and the growth of household debt, characterized the US experience over the 3 decades up until the outbreak of the financial and economic crisis of 2007 (see Barba and Pivetti 2009).

In assessing the possibility that financial constraints have impaired the expansion of investment, it seems important not to lose sight of two points. First, it is precisely because of the recorded change in income distribution that firms hardly faced any problem of relative scarcity of internal funds; second, for most of the period under review, easier access to credit and a marked easing of liquidity constraints concerned not only

8. In fact, US data for the private non-farm business sector show for the 1978-2007 period a significant slowing down of the rise in output per hour (and, for what it's worth, also in the so-called multi-factor productivity) with respect to the previous 30-year period (see US Bureau of Labor Statistics 2011, Tables XG 2b and XG 4b). 
households but firms as well. It seems therefore difficult to believe that overall investment was not kept at the higher plateau of the former 30-year period because of a shortage of funds. Neither the availability of corporate profits for investment, nor the narrowness of the credit channel as a whole may be invoked as a binding constraint on investment.

It should also be noted that, over the last few decades, the non-financial corporate sector continued to hold rising volumes of financial assets. This confirms the absence of financial constraints on investment, while suggesting at the same time that it was primarily the weakening of the inducements to invest that improved the attractiveness of financial investments, rather than the other way round. Of course, this does not imply a denial that the establishment of a climate of feverish speculation may end up making real the risk of a predominance of speculation over enterprise. But to acknowledge that enterprise may be overwhelmed by speculation is something different from arguing that speculation subtracts funds from enterprise. If one follows Keynes in referring to 'speculation' as the activity of forecasting the psychology of the market, and to 'enterprise' as the activity of forecasting the prospective yield of assets over their whole life, then one will easily recognize that besides the possible presence of factors encouraging speculation, there may be factors that operate independently in discouraging enterprise. And if the financial mess actually experienced by advanced capitalism is further recognized as having been an effect rather than a cause of the presence in the system of imbalances of a real nature, then the root of speculation itself will be traced back to a situation in which 'investment based on genuine long-term expectations [has become] so difficult as to be scarcely practicable' (Keynes 1936 [1964], p. 157). From this point of view, a negative impact of the speculative frenzy on investment should be acknowledged for the aftermath of the financial crisis and the ensuing credit crunch, rather than for the years of the booming real and financial assets. ${ }^{9}$

Even in a context where liquidity constraints on investment are absent, the development of finance may influence capital formation through its impact on income distribution. It is well known that during the last 3 decades the sector of credit and insurance grew markedly; it is also known that profits in this sector grew even more than its value added, up to the point of reaching, in the United States at the beginning of the new millennium, about half the total profits that the US economy as a whole was capable of generating. It is obvious that if the rate of profit in the financial sector had been aligned to the lower profit rate of the non-financial sector, the share of wages in value added would have been greater. It can therefore be affirmed that the development of finance did have a negative impact on investment, but through its impact on income distribution.

We must finally consider the role of finance as a means of disconnecting the behaviour of final demand from that of distribution. Finance can play such a role either by giving direct support to consumer spending, or through wealth effects. We have already referred to the first of these two possibilities when we recalled above the process of substitution of loans for wages and the growth of household debt. The second

9. For an analysis which emphasizes instead capital gains as a factor likely to have exerted a dampening effect on investment, by attracting funds away from the real to the financial sector, see, for example, Bhaduri 2011, pp. 10-11. Hein (2009) holds similar views, by arguing that an 'increasing shareholder power vis-à-vis management and labourers, an increasing rate of return on equity and bonds held by rentiers and decreasing managements' animal spirits with respect to real investment in capital stock' (p. 50) would have had a negative effect on real investment. 
route concerns the support given to the propensity to consume of people who benefited from the increased values of their real and financial assets, independently of whether, in the face of those increased values, they had recourse to debt through equity withdrawals, or reduced instead their savings without recourse to debt. Today we know, however, that the wealth effects in question were temporary. So in the long run debt and wealth effects, either because the growth of private debt is unsustainable or because wealth effects are transient, cannot guarantee a permanent disconnection between changes in distribution and final demand.

We can conclude that the overall effect on investment of the financial sector enlargement, in size and scope, was negative: it contributed to bring about a change in income distribution unfavourable to the expansion of demand, while providing only a temporary disconnection of demand from the distributive change. That said, it remains true that the debt and wealth effects just considered did have a positive, though temporary, influence on activity levels and hence on investment. This largely explains the different impact that the change in distribution exerted on final demand and accumulation in the Anglo-Saxon world, on the one hand, and in most of continental Europe, on the other - the fact, that is to say, that over the 30 years up to the crisis investment grew significantly faster in the former than in the latter context.

\section{AUSTERITY AND THE PRIVATIZATION DRIVE}

As is known, Europe has responded to the crisis and the ensuing recession with unprecedented programmes of fiscal austerity. There is a significant element of continuity between the current European economic policy of austerity and the process of substitution of loans for wages experienced by a large section of advanced capitalism up to the 2007 crisis. Both can be read as attempts to ensure a continued expansion of profits and top management income disconnected from the expansion of the other incomes. Austerity, as we shall now proceed to argue, is trying to bring about this result in a context of stagnation through a process of substitution of private capital to already existing collective capital.

The explicit objective of the European economic policy of austerity is not just the attainment of primary surpluses, independently of how they are actually brought about; it is rather the attainment of 'healthy public finances' through reductions in government spending that are sufficiently severe as to allow also for reductions in income taxation. The neoclassical theoretical justification of this policy stance has a bearing upon the question of the relationship between income distribution and accumulation. According to the orthodox way of reasoning, the reduced redistributive intervention of the state would ultimately increase, through reduced income taxes, the supply both of labour and savings, and thus foster capital accumulation. Outside this traditional neoclassical framework, there is hardly any room left for the possibility of conceiving that austerity may exert some positive impact on accumulation and growth. Rather, through its negative impact on employment and wage earners' bargaining power, austerity is bound to reinforce the vicious circle which underlay the slowdown of accumulation over the last 30 years - higher unemployment, worsening distributive conditions, anaemic expansion of final demand, increasingly weak inducements to invest.

The only inducement to invest that austerity is most likely to generate is that linked to the room that is being left in Europe to private enterprise by the gradual dismantling of the welfare state - that is, to the withdrawal of the state from the provision of essential services. These services - from health to education, from pensions to public transport 
and housing - are especially coveted by private capital: their weight in final demand is increasing in all industrially advanced economies; their consumption cannot be compressed below certain levels without impairing the quality of the available work force, so that they are likely to be often directly or indirectly subsidized by the government (think of the case of high education in the USA, whose eminently private regime is sustained by rising volumes of student loans, which, if not honoured, do benefit from the indirect guarantee of the government); finally, their production is hardly exposed to foreign competition at all.

But this privatization drive does not produce any gross fixed capital formation; it merely constitutes a substitution of private capital for already existing collective capital - a substitution which, by itself, does not add a single piece of equipment to the economy's productive structure. From the point of view of overall capital formation, the outcome is similar to that resulting from processes of concentration and centralization occurring all the time within the private sector, and by which the investments of some capitalists are simply substituted by the disinvestments of others. From the point of view of income distribution, however, the substitution achieved through the process of privatization of collective services is all but neutral.

Privatizations have a negative impact on real wages through various channels. They make it necessary, of course, that the production of services previously provided for by the state is rendered profitable to private capital. Room for previously absent profit margins is thus created, on the one hand, through higher prices, and, on the other, through reductions in the number of people employed in their production, in the level of protective legislation accorded to them, and, ultimately, in the quality of the services produced. The financial costs of the acquisitions then add to the prices of the privatized services; these costs naturally must include the additional profits that privatization brings for the financial sector.

The point we wish to stress here is that the privatization process is unable to sustain accumulation and check the tendency to stagnation. There is no way in which one can reasonably conceive of privatization as an engine of growth alternative to the expansion of final demand. In a context of falling wages, growth can be brought about only by a process of substitution of loans for wages, which is however financially unsustainable in time, as actual experience has shown us beyond all possible doubt (cf. Barba and Pivetti 2009, pp. 127-131).

\section{THE QUESTION OF LONG-RUN SOCIAL STABILITY}

From the perspective of capital owners as a class, a process of real wages contraction may seem significantly preferable as a route to the expansion of the mass of profits over time than a process of continuous expansion and renewal of productive capacity. The problem is that the former process is unsustainable, no matter whether it takes place directly, through wage bargaining in situations of decreasing wage earners' strength, or whether it occurs through the 'hazier' means of the gradual dismantling of the welfare state that is, through the contraction of indirect wages. ${ }^{10}$ With the austerity programmes, the role of this 'hazier' way is becoming increasingly relevant as the European route to the expansion of profits, and, as pointed out in the previous section, its impact on income distribution could hardly be overrated. We may add now that not only must the financial costs and mark-up pricing of privatized services be taken into account,

10. For an analysis of the Italian experience over the last 30 years, see Barba 2011. 
but also the fact that, due to the reduced progressivity of the tax system, wage earners are increasingly burdened with the cost of the residual social expenditures.

In the medium-to-longer run, however, the overall expansion of profits and top management income cannot be secured merely by a prolonged appropriation of wages on the part of capitalists and their representatives. That expansion must instead necessarily occur in connection with that of the income of all the main social classes and groups, for the legitimacy of the social system not to be called into question sooner or later. It is worthy of note, in this respect, that in spite of the optimistic tendency which developed over the last few decades to 'assume some of the most peculiar and temporary of our late advantages as natural and permanent' (Keynes 1919 [1971], p. 1), apprehensions are now surfacing here and there, but especially in the US, that an unravelling of the fabric of democracy and a rejection of the social system as a whole might follow from the progressive worsening of the distributive conditions and a rising state of popular unrest, political violence, demands for radical changes and increasing social and political instability. ${ }^{11}$

Unlike in the USA, where social and political stability have indeed always been viewed as resting essentially on growth, in Europe a situation of relative social stability was reached, and long maintained, thanks precisely to the development of a generous social democratic welfare order, largely financed by markedly progressive taxation systems. Now, the economic policy of austerity ultimately rests on the implicit assumption that social stability would constitute in Europe a definitively attained goal, not likely to be challenged by the giving up of those very policies directed towards income redistribution that brought it about. This implicit assumption can actually be regarded as the chief element of obtuseness present in the current austerity programmes.

The illusion of social stability as a definitively attained goal certainly gained momentum in Europe with the Treaty of Maastricht and the other institutional changes produced subsequently by the various treaties and pacts that accompanied the development of the European project for arriving at economic and monetary union. The surrender of national sovereignty in the monetary and fiscal fields subscribed by European governments produced a situation of 'political irresponsibility', which greatly facilitated in Europe a declining commitment to high employment and the redistribution of wealth, as well as the priority given to reducing inflation, the gradual dismantling of the welfare state and the privatization drive. ${ }^{12}$ Without the institutional changes linked to the European project, actual policymaking in Europe could hardly have been capable of becoming single-mindedly focused on fighting inflation. Those changes forcibly signalled that the unification of the continent made this focus unavoidable; they also made it appear that, in the monetary and fiscal fields, a 'sticking to rules' enforced from the outside was ineluctable.

11. See, for example, Alesina and Perotti 1993; Acemoglu 2009, p. 5; OECD 2011.

12. Think, by contrast, of the US case, where since the mid-1980s the inflation rate has never become the overriding policy objective. There, a situation of substantially unlimited national sovereignty deprives policymakers of any pretext: employment and growth must be sustained almost at any cost if the certain loss of political consensus is to be avoided. In the US, moreover, owing to the older and much more marked declining influence of the unions, relatively high levels of unemployment have long become less necessary to check wage-earners' bargaining power and allow significant changes in distribution in favour of the wealthier sections of the population. 
One should not forget that certain principles and ideas originally developed in American academic circles, but whose influence on actual policymaking in the US context has been close to zero, gave strong theoretical support to the institutional changes under consideration. We refer especially to the notion that, in order to avoid the inefficiency that would arise when policy is formulated in a discretionary manner, the best solution is to delegate it to bodies insulated from national governments; more generally, to the idea that overall policymaking - that is, both monetary and budgetary policy - in the hands of independent technocrats, rather than politicians, should be seen as the most appropriate route to economic stability and long-run welfare. One could hardly deny the influence that such principles and ideas have exerted on the European process of progressive surrender of national sovereignty in the economic sphere, and, through this process, on the distributive change suffered by continental Europe. It is just sensible to expect that they will be swept away and readily forgotten, as soon as the question of the system's legitimacy is brought back to the forefront by non-episodic and rising manifestations of social discontent.

The fact however remains that up to now, and during all the years after about 1980, all the main political forces in Europe have kept sharing principles and ideas such as those just referred to, together with the conviction that surrendering national sovereignty in the economic sphere would have fostered 'the construction of Europe', and, in the process, would have benefited the real economy as well. The European Left, in particular, did not simply testify in stupor to the epoch-making shift away from the stability and social justice achieved in post-war Western Europe; indeed, the Left's amazing cultural subalternity throughout this period made her often the chief endorser and very executor of the neoliberal policy consensus. Hence the paradox of a 30-year period of rising economic inequalities accompanied by an increasing actual homogeneity between the political forces operating on the scene. This European paradox is all but the other side of the coin of the widespread illusion that in Europe social stability is not really at risk, and of the ensuing stubbornness of the economic policy of austerity.

The overall prospective picture one derives from our analysis is rather bleak. At the present time, no primum movens can be detected, in the light of the framework of interconnections between income distribution and accumulation that we have been putting forward, which may be thought of as capable of re-setting in motion a virtuous circle, somewhat comparable to that experienced by advanced capitalism over the 30-year period before the divide of the late 1970s. Both in the USA and in Europe, the progressive breakdown of wage earners' bargaining power that has tended to feed upon itself through its impact on final demand and the inducement to invest, appears most likely to move still further, up to the point of eventually calling into question the very legitimacy of the social system. Some critics of capitalism might be tempted to rejoice at this, and think that, after all, one should be grateful to the theoretical restoration of the last 30 years, in that it helped bringing about such an unchecked predominance of the market ideology, thereby paving the way for the beginning of the end. Though there is something in the notion that advanced capitalism, with the explosion of its income inequalities, is digging its own grave, we feel unable to share any contentment about it. The 'beginning of the end' can be an extremely long and painful process, and even if you could maintain that in the end everything would turn out much better, 'there is a short run which is important, and makes a great deal of difference to a great many people' (Carr 1987, p. 169). 
142 Review of Keynesian Economics, Inaugural Issue

\section{REFERENCES}

Acemoglu, D. (2009), 'The crisis of 2008: structural lessons for and from economics', Centre for Economic Policy Research, Policy Insight No 28, 1-6 January.

Alesina, A. and Perotti, R. (1993), 'Income distribution, political instability, and investment', NBER Working Paper, 4486.

Barba, A. (2011), 'La redistribuzione del reddito nell'Italia di Maastricht', in L. Paggi (ed.), Un'altra Italia in un'altra Europa. Mercato e Interesse Nazionale, Roma: Carocci.

Barba, A. and Pivetti, M. (2009), 'Rising household debt: its cause and macroeconomic implications - a long-period analysis', Cambridge Journal of Economics, 33(1): 113-137.

Bhaduri, A. (2011), 'Financialization in the light of the Keynesian theory', PSL Quarterly Review, 64: 7-21.

Carr, E.H. (1987), What is History? Harmondsworth: Penguin Books.

Council of Economic Advisers (1995), The Annual Report, Washington, DC: USGPO.

Council of Economic Advisers (2010), The Annual Report, Washington, DC: USGPO.

Hein, E. (2009), 'A (post) Keynesian perspective on financialization', IMKStudies, 01-2009, IMK at the Hans Boeckler Foundation, Macroeconomic Policy Institute.

Keynes, J.M. (1919 [1971]), 'The economic consequences of the peace', in E.D. Moggridge (ed.), The Collected Writings of John Maynard Keynes, Vol. II, London: Macmillan.

Keynes, J.M. (1936 [1964]), The General Theory of Employment, Interest and Money, London: Macmillan.

Mishel, L., Bernstein, J. and Shierholz, H. (2009), The State of Working America, 2008-2009, Ithaca, NY: Cornell University Press.

OECD (2001), Economic Outlook, Paris: OECD Publications.

OECD (2002), Foreign Direct Investment for Development, Maximising Benefits, Minimising Costs, Paris: OECD Publications.

OECD (2005), Enhancing the Performance of the Services Sector, Paris: OECD Publications.

OECD (2011), Divided We Stand. Why Inequality Keeps Rising, Paris: OECD Publications.

Pivetti, M. (2009), 'Interest and the general price level: some critical notes on the "The new consensus monetary policy model"', in A. Birolo, D.C. Foley, H.D.Kurz, B. Schefold and I. Steedman (eds), Production, Distribution and Trade: Alternative Perspectives. Essays in Honour of Sergio Parrinello, London and New York: Routledge.

Pivetti, M. (2011), 'Le strategie dell'integrazione europea e il loro impatto sull'Italia', in L. Paggi (ed), Un'altra Italia in un'altra Europa. Mercato e Interesse Nazionale, Roma: Carocci.

Salverda, W. and Mayhew, K. (2009), 'Capitalist economies and wage inequalities', Oxford Review of Economic Policy, 25(1), 124-154.

UNCTAD (2010), World Investment Report 2010, New York: United Nations.

US Bureau of Labor Statistics (2011), Office of Productivity and Technology, Analytical Ratios and Indexes, May. 